http://dx.doi.org/10.11646/phytotaxa.174.5.7

\title{
A new species of Trocholejeunea (Lejeuneaceae, Marchantiophyta) from China
}

\author{
JIAN WANG ${ }^{1,3}$, S. ROBBERT GRADSTEIN ${ }^{2}$, XIA-FANG CHENG ${ }^{1}$ \& RUI-LIANG ZHU ${ }^{1,3}$ \\ ${ }^{1}$ Bryology Laboratory, School of Life Science, East China Normal University, 500 Dongchuan Road, Shanghai 200241, China; email: \\ jwang@bio.ecnu.edu.cn \\ ${ }^{2}$ Muséum National d'Histoire Naturelle, Dept. Systématique et Evolution, Case Postale 39, 57 rue Cuvier, 75231 Paris cedex 05, \\ France; email: gradstein@mnhn.fr \\ ${ }^{3}$ Author for correspondence
}

\begin{abstract}
Trocholejeunea sinensis J.Wang bis, R.L.Zhu \& Gradst. sp. nov. (Lejeuneaceae) is described and illustrated based on specimens collected from Guangxi and Yunnan, China. The new species differs from all other species of Trocholejeunea by the presence of an "extra" lobule tooth situated at the extreme end of the free margin, near the junction of the lobule and the lobe. A key to the species of Trocholejeunea is provided.
\end{abstract}

Key words: Guangxi, liverworts, Ptychanthoideae, taxonomy, Yunnan

\section{Introduction}

Trocholejeunea Schiffner in Dixon et al. (160:1932) is an Asiatic genus of Lejeuneaceae subfamily Ptychanthoideae Mizut. with four species (Mizutani, 1989; Singh \& Nath, 2008). The genus is characterized by predominantly Frullaniatype branching, absence of flagella, entire underleaves and entire margins of leaf lobes, cordate trigones, homogeneous oil bodies, epistatic male bracts, presence of Frullania-type innovations or occasionally of Radula-type innovations, perianth with 6-10 keels, non-articulate seta with 16-17 rows of outer cells and 8-10 rows of inner ones (Gradstein, 1975; Thiers, 1985; Gradstein et al., 2002; Zhu \& So, 2001). Trocholejeunea is most closely related to Acrolejeunea (Spruce 1884: 115) Schiffner (1893: 128), which is distinguished by the occasional presence of flagella, predominantly Lejeunea-type branching, absence of innovations, articulate seta with 16 outer cell rows and 4 inner cell rows (Zhu \& So, 2001). In addition, the two genera differ in the size and shape of the male bracts which are equal to vegetative leaves in Trocholejeunea but slightly smaller than vegetative leaves and with more strongly inflated lobule in Acrolejeunea.

In the course of our study Lejeuneaceae subfam. Ptychanthoideae from China, we found two collections from Guangxi and Yunnan which were quite different from other species of Trocholejeunea. A new species, Trocholejeunea sinensis J.Wang bis, R.L.Zhu \& Gradst., is here described and illustrated. In addition a key to the species of Trocholejeunea is provided.

Trocholejeunea sinensis J.Wang bis, R.L.Zhu \& Gradst., sp. nov. (Figs. 1-2)

A new species characterized by the branches usually of Frullania-type and occasionally of Lejeunea-type; the hexagonal median cells with cordate trigones and homogeneous oil bodies; the lobule always with 3 teeth and the first tooth situated at the extreme end of the free margin near the junction of the lobule and the lobe; the gynoecia with 1-2 Frullania-type innovations; and the perianths with 9-10 straight or somewhat flexuose keels.

Type:-CHINA. Guangxi. Jinxiu Co., Dayaoshan National Nature Reserve, Cathaya argyrophylla Protection Station, on rotten logs, 900-1000 m, 19 Jul. 2009, Wen Ye \& Yu-Mei Wei 20090719-47A (holotype HSNU!).

Dioicous? (Androecia not seen). Plants 1.6-2 cm long, 1.1-1.8 mm wide, yellowish green, brown when dry, irregularly branched, branches predominantly of the Frullania-type (long branches), occasionally of the Lejeunea-type (short branches). Stems $0.12-0.16 \mathrm{~mm}$ in diameter, ventral merophyte 4-6 cells wide, stem in transverse section with 14-15 cortical cells and 20-21 medullary cells. Rhizoids few, fasciculate, brown, rhizoid disc absent. Leaves imbricate, 


\section{Acknowledgements}

Thanks are due to Dr. Wen Ye of South China Botanical Garden, Chinese Academy of Sciences and Dr. Yu-Mei Wei of Guangxi Institute of Botany, Chinese Academy of Sciences for the collection of specimens. This research was supported by the National Natural Science Foundation of China (nos. 31170190, 31300171), the Special Program for the National Basic Work of the Ministry of Science and Technology, China (No. 2012FY110600), and PhD Program Scholarship Fund of ECNU 2009.

\section{References}

Dixon, H.N., Schiffner, V., Verdoorn, F. (1932) Bryophyta nova (1-5). Annales Bryologici 5: 157-164.

Gradstein, S.R.(1975)A taxonomic monograph of the genus Acrolejeunea (Hepaticae) with an arrangement of the genera of Ptychanthoideae. Bryophytorum Bibliotheca 4: 1-162.

Gradstein, S.R., He, X.-L., Piippo, S. \& Mizutani, M. (2002) Bryophyte flora of the Huon Peninsula, Papua New Guinea. LXVIII. Lejeuneaceae subfamily Ptychanthoideae (Hepaticae). Acta Botanica Fennica 174: 1-88.

Mizutani, M. (1961) A revision of Japanese Lejeuneaceae. Journal of the Hattori Botanical Laboratory 24: 115-302.

Mizutani, M. (1989) Notes on the Lejeuneaceae. 15. Three species of the genus Trocholejeunea. Journal of the Hattori Botanical Laboratory 66: 271-281.

Singh, A.P. \& Nath, V. (2008) A new species of Trocholejeunea (Hepaticae: Ptychanthoideae) from Meghalaya, Eastern Himalayas, India. The Journal of Japanese Botany 83: 1-6.

Schiffner, V. (1893) Hepaticae. In: Engler, A. \& Prantl, K.A.E. (Eds.) Die Natürlichen Pflanzenfamilien 1. W. Engelmann, Leipzig, pp $3-141$.

Spruce, R. (1884) Hepaticae Amazonicae et Andinae. Transactions and Proceedings of the Botanical Society of Edinburgh 15: 1-590.

Taylor, T. (1846) New Hepaticae. London Journal of Botany 5: 365-417.

Thiers, B.M. (1985) Branching in Lejeuneaceae III: Ptychanthoideae. In: Gradstein, S.R. (Ed.) Contributions to a monograph of the Lejeuneaceae subfamily Ptychanthoideae. Beihefte zur Nova Hedwigia 80: 31-61.

Zhu, R.-L. \& Gradstein, S.R. (2005) Monograph of Lopholejeunea (Spruce) Schiffn. (Lejeuneaceae, Hepaticae) in Asia. Systematic Botany Monographs 74: 1-98.

Zhu, R.-L. \& So, M.-L. (2001) Epiphyllous liverworts of China. Nova Hedwigia Beiheft 121: 1-418. 